\title{
Unit of Energy
}

National Cancer Institute

\section{Source}

National Cancer Institute. Unit of Energy. NCI Thesaurus. Code C67275.

An indication of the type of unit of measure being used to express energy. 